\section{Short-duration Presprouting, Ethephon, and Cutting Increase Plant Production by Sweetpotato, Roots}

\author{
Melvin R. Hall ${ }^{1}$ \\ Department of Horticulture, University of Georgia Coastal Plain \\ Experiment Station, Tifton, GA 31793
}

Additional index words. Ipomoea batatas, transplants, propagation

Abstract. Sweetpotato [ Ipomoea batatas (L.)] plants were harvested earlier following immersion of roots in $1500 \mathrm{mg}$ ethephon/liter for 10 minutes or cut transversely 1 to $2 \mathrm{~cm}$ from the proximal end before bedding than when roots were not treated. Combined ethephon and cutting treatments did not promote earlier harvests than either applied separately. Presprouting for 10 days reduced the time to first plant harvest from whole or cut roots of 'Georgia Red', but not from roots of 'Georgia Jet'. Immersion in ethephon increased the number of early and total plants produced by both cultivars. Short-duration presprouting and cutting of roots increased the number of early and total plants produced by 'Georgia Red', but not by 'Georgia Jet'. Total plant production was increased by cutting non-presprouted roots that had been immersed in ethephon. Cutting did not significantly increase total plant production from presprouted roots, but immersion in ethephon increased total number of plants produced from presprouted whole roots. Plant weight and deterioration of the bedded roots during plant propagation were not influenced by treatments. Chemical name used: (2chloroethyl)phosphonic acid (ethephon).
Propargation of plants from bedded roots is a major cost of commercial sweetpotato production in the United States, and cultivars Treatments that decrease the interval from bedding to plant harvest or increase the total number of plants from bedded roots can help reduce the cost of propagation and may be beneficial for both profuse and sparse plantproducing cultivars. Holding roots under presprouting conditions $(32 \pm 1 \mathrm{C}, 85 \% \mathrm{RH})$ for $\approx 3$ weeks before bedding is a standard (Deonier and Kushman, 1960). Shorter durations of presprouting (Hall, 1987), immersion in ethephon (Tompkins and Bowers, 1970; Tompkins and Horton, 1973, 1974), and cutting (Kushman et al., 1970) also increase plant production, but the combined influence of these three factors on plant production has not been reported. The objective of this study was to determine the influence of short-duration presprouting, immersion in ethephon, and cutting on plant production from bedded roots of a profuse and a sparse plant-producing cultivar. $5.0 \mathrm{~cm}$ in diameter, 5.0 to $18 \mathrm{~cm}$ in length),

Received for publication 8 May 1989. Use of trade names does not imply endorsement by the Georgia Agricultural Experiment Stations of the products named nor criticism of similar products not mentioned. This research was supported by state and Hatch Act funds allocated to the Georgia Agricultural Experiment Stations. The cost of publishing this paper was defrayed in part by the payment of page charges. Under postal regulations, this paper therefore must be hereby marked advertisement solely to indicate this fact.

Associate Professor. vary in their plant production potential. method of increasing plant production

Three weeks after harvest, small (2.5 to cured $(32 \pm 1 \mathrm{C}$ and $85 \% \pm 5 \% \mathrm{RH}$ for 7 days) sweetpotato roots of the profuse plantproducing cultivar Georgia Red and the sparse plant-producing cultivar Georgia Jet were removed from storage $(16 \pm 1 \mathrm{C}$ and $85 \% \pm$ $5 \% \mathrm{RH}$ ) and randomly assigned to 10 -root lots. Thirty-two lots were prepared for each cultivar. 'Georgia Red' lots weighed $967 \pm$ $22 \mathrm{~g}$ and 'Georgia Jet' lots $812 \pm 19 \mathrm{~g}$. One half of the lots of each cultivar were returned to storage conditions and the other one half was subjected to presprouting conditions ( 32 $\pm 1 \mathrm{C}$ and $85 \% \pm 5 \% \mathrm{RH}$ ) for 10 days. After removing from storage or presprouting conditions, each lot was either immersed for $10 \mathrm{~min}$ in $1500 \mathrm{mg}$ ethephon/liter (Tompkins and Horton, 1973) or not immersed and either cut transversely 1 to $2 \mathrm{~cm}$ from the proximal end (Thompson and Beattie, 1932) or left whole. Next, each lot was immersed for 15 $\mathrm{sec}$ in a fungicide solution prepared with 640 $\mathrm{g}$ of $75 \%$ wettable powder 2,6-dichloro-4nitroaniline (dicloran) in 40 liters of water, and air dried. Lots were then placed in 30 $\times 40-\mathrm{cm}$ contiguous plots in a $3.2 \times 4.8$ $m$ greenhouse bed and covered with $5 \mathrm{~cm}$ of fumigated Tifton loamy sand (fine-loamy, siliceous, thermic Plinthic Paleudults). Plots were watered immediately after bedding and thereafter as needed (when the bed surface was dry to a depth of $1 \mathrm{~cm}$ ) to ensure adequate moisture levels for plant production. After the first plant harvest, granular fertilizer $\left[28.0 \mathrm{~N}-12.3 \mathrm{P}-23.2 \mathrm{~K}\left(\mathrm{~g} \cdot \mathrm{m}^{-2}\right)\right]$ was broadcast over the bed surface before application of $5 \mathrm{~mm}$ of water. Air minimum in the greenhouse was $24 \mathrm{C}$ and the soil was at $28 \pm 4 \mathrm{C}$.

Only plants $20 \mathrm{~cm}$ or more above the bed surface were harvested, and plots were harvested individually starting when the first plant in a plot was $20 \mathrm{~cm}$ above the bed surface. The initial plant harvest date varied by 5 weeks for the various treatment combinations. Including the initial harvest, plants were pulled at five consecutive weekly intervals of a 9week total period. Plants from individual plots were counted and weighed after each har-
Table 1. Effects of cultivar, 10-day presprouting, immersion in $1500 \mathrm{mg}$ ethephon/liter, and transverse cutting 1 to $2 \mathrm{~cm}$ from the proximal end on plant production after five consecutive plant harvests during a 9-week harvest period from plots of 10 bedded sweetpotato storage roots.

\begin{tabular}{|c|c|c|c|}
\hline \multirow[b]{2}{*}{ Variables } & \multirow{2}{*}{$\begin{array}{l}\text { First plant harvest } \\
\text { (days from bedding) }\end{array}$} & \multicolumn{2}{|c|}{ Plants per plot (no.) } \\
\hline & & Earlyy & Total \\
\hline \multicolumn{4}{|l|}{$\overline{\text { Cultivar (C) }}$} \\
\hline Georgia Red & 46 & 20 & 26 \\
\hline Georgia Jet & 56 & 2 & 6 \\
\hline Significance & $*$ & $* *$ & $* *$ \\
\hline \multicolumn{4}{|l|}{ Presprouted $(\mathrm{P})$} \\
\hline No & 52 & 6 & 12 \\
\hline Yes & 49 & 12 & 17 \\
\hline Significance & NS & $* *$ & $* *$ \\
\hline \multicolumn{4}{|l|}{ Ethephon (E) } \\
\hline No & 55 & 6 & 11 \\
\hline Yes & 47 & 13 & 19 \\
\hline Significance & $* *$ & $* *$ & $* *$ \\
\hline \multicolumn{4}{|l|}{ Roots cut (R) } \\
\hline No & 53 & 5 & 9 \\
\hline Yes & 49 & 13 & 21 \\
\hline Significance & NS & $* *$ & ** \\
\hline \multirow[t]{2}{*}{ Significant interactions } & $\mathrm{C} \times \mathrm{R}^{* *}$ & $\mathrm{C} \times \mathrm{P}^{* *}$ & $\mathrm{C} \times \mathrm{P}^{*}$ \\
\hline & $\begin{aligned} E & \times R^{* *} \\
C & \times P \times R^{* *}\end{aligned}$ & $\mathrm{C} \times \mathrm{R}^{* *}$ & $\begin{array}{c}\mathrm{C} \times \mathrm{R}^{* *} \\
\mathrm{P} \times \mathrm{R}^{*} \\
\mathrm{P} \times \mathrm{E} \times \mathrm{R}^{*}\end{array}$ \\
\hline
\end{tabular}

${ }^{2}$ Means within main effects within columns pooled across other main cffects and four replications. Means do not average because of rounding and because analyses were conducted on transformed data, and back-transformed means are presented.

${ }^{y}$ Cumulative number of plants harvested at any time during the first five of the nine weekly harvests. Ns,*,**Nonsignificant or significant at $P=0.05$ or 0.01 , respectively. 
Table 2. Influence of immersion in $1500 \mathrm{mg}$ ethephon/liter and transverse cutting 1 to $2 \mathrm{~cm}$ from the proximal end on days from bedding until first plant harvest from plots of 10 bedded sweetpotato storage roots.

\begin{tabular}{llrc}
\hline \hline & \multicolumn{2}{c}{ Root cut $^{2}$} & \\
\cline { 2 - 3 } Ethephon & No & Yes & Significance \\
\hline \multirow{3}{*}{ Days } & $*$ \\
No & 61 & 50 & $*$ \\
Yes & 45 & 48 & NS \\
Significance & $* *$ & NS & \\
\hline
\end{tabular}

${ }^{2}$ Means do not average because of rounding and because analyses were conducted on transformed data, and back-transformed means are presented.

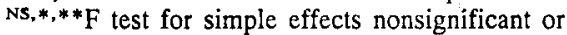
significant at $P=0.05$ or 0.01 , respectively.

vest. Data presented include the cumulative number of plants harvested at any time during the first five of the nine weekly harvests (early plants) and the total number of plants harvested during the 9 weeks, regardless of when the five consecutive weekly harvests occurred during those 9 weeks. After the fifth plant harvest from individual plots, bedded roots were removed and evaluated for severity of deterioration. A root was classified as deteriorated if one half or more was decayed. Data were subjected to a $(x+$ $0.5)^{1 / 2}$ transformation for analyses and transformed means were back-transformed for presentation. The experimental design was a $2 \times 2 \times 2 \times 2$ factorial in a split-splitsplit-plot with four replications. Cultivars were main plots, presprouting treatments were subplots, ethephon immersion treatments were sub-sub-plots, and cutting treatments were sub-sub-sub-plots. Each replication contained 16 sub-sub-sub-plots. Each sub-subsub-plot was a 10-root lot, as described above, of either 'Georgia Jet' or 'Georgia Red', with a combination of treatments of presprouted or not presprouted, immersed. or not immersed in ethephon, and cut or not cut.

Immersion in ethephon tended to decrease the time interval from bedding until first plant harvest (Table 1), and lack of interactions with main effects for cultivar or presprouting indicated that ethephon reduced this time interval with both cultivars whether or not roots were presprouted. Immersion in ethephon or transverse cutting at the proximal end decreased the time interval from bedding until first plant harvest, but a combination of ethephon and cutting was no more effective than either treatment alone (Table 2). Cutting of nonpresprouted roots reduced the time interval from bedding until first plant harvest from 59 days to 40 days ( $P=0.01$ ) for 'Georgia Red', but increased the time interval to 62 days from 50 days $(P=0.01)$ for 'Georgia Jet'. Presprouting reduced the time interval by 14 days for uncut 'Georgia Red' $(P=$ 0.01 ), but the interval was unchanged for uncut 'Georgia Jet' roots or cut roots of either cultivar (data not shown).

Ethephon treatment enhanced early and total plant production, and lack of interaction with cultivar main effect indicates that immersion in ethephon increased early and total plant production of both cultivars (Table 1). Also, lack of interaction indicates that immersion in ethephon further enhanced the increase in the number of early plants induced by presprouting, and cutting further enhanced the increase in early plants induced by immersion in ethephon. Cutting also further enhanced the increase in the number of early plants induced by short-duration presprouting.

Presprouting for 10 days increased early plant production of 'Georgia Red' (28 vs. 13 plants; $P=0.05)$, but not 'Georgia Jet' (2 vs. 2 plants). Presprouting also increased total plant production of 'Georgia Red' (33 vs. $21 ; P=0.01$ ), but not 'Georgia Jet' (6 vs. 5 ). Transverse cutting at the proximal end of the root increased the number of early plants (35 vs. $9 ; P=0.01)$ and total plants (42 vs. $15 ; P=0.01)$ of 'Georgia Red', but not 'Georgia Jet' ( 2 vs. 2 and 4 vs. 8 for early and total plants, respectively). These results differ from previous findings for 'Georgia Jet', where 9-day presprouting caused an increase in early and total plant production from large roots that had been stored for 3 months (Hall, 1987). However, the current results are similar to other findings for 'Georgia Jet', where transverse cutting of the root at the proximal end did not increase plant production (Hall, 1986).

A significant presprouting $\times$ ethephon $\times$ cutting interaction was evident for total plant

Table 3. Influence of 10-day short-duration presprouting, immersion in $1500 \mathrm{mg}$ ethephon/liter, and transverse cutting 1 to $2 \mathrm{~cm}$ from the proximal end on total number of plants harvested per plot from plots of 10 bedded sweetpotato storage roots.

\begin{tabular}{|c|c|c|c|c|}
\hline \multirow[b]{2}{*}{ Presprouted } & \multirow[b]{2}{*}{ Ethephon } & \multicolumn{2}{|c|}{ Roots cut ${ }^{z}$} & \multirow[b]{2}{*}{ Significance } \\
\hline & & No & Yes & \\
\hline \multicolumn{5}{|c|}{ No. of plants } \\
\hline \multirow[t]{3}{*}{ No } & No & 5 & 14 & $* *$ \\
\hline & Yes & 6 & 28 & ** \\
\hline & Significance & NS & $*$ & \\
\hline \multirow[t]{3}{*}{ Yes } & No & 8 & 18 & NS \\
\hline & Yes & 19 & 27 & NS \\
\hline & Significance & * & NS & \\
\hline
\end{tabular}

${ }^{z}$ Means do not average because of rounding and because analyses were conducted on transformed data, and back-transformed means are presented.

Ns.*,**F test for simple effects nonsignificant or significant at $P=0.05$ or 0.01 , respectively.

production (Table 1). Total plant production was enhanced by cutting roots that had not been presprouted, and the effect was more pronounced when roots had been immersed in ethephon (Table 3 ). However, cutting did not cause significant increases in total plant numbers when roots were presprouted, and ethephon increased total plant production from whole, but not from cut, roots.

Plant weights, $9.7 \mathrm{~g}$ for 'Georgia Red' and $10.5 \mathrm{~g}$ for 'Georgia Jet', were not influenced by treatments and all harvested plants were of suitable size for transplanting. Nearly 35\% of the bedded roots were at least one-half deteriorated when removed from the plant bed, but there were no differences attributable to treatments (data not shown).

Tompkins and Horton (1973) showed that ethephon maybe as effective as presprouting for increasing plant production from sparse to fair plant-producing cultivars. The present study indicates that ethephon decreases days to first plant harvest from the plant bed and increases early and total plant production of 'Georgia Red' or 'Georgia Jet'. Furthermore, ethephon in combination with 10-day presprouting and transverse cutting 1 to $2 \mathrm{~cm}$ from the proximal end increased or tended to increase early and total plant production from the profuse plant-producing cultivar Georgia Red and from the sparse plant-producing cultivar Georgia Jet. Although ethephon is not commercially used on sweetpotato, these findings and earlier information (Tompkins and Bowers, 1970; Tompkins and Horton, 1973, 1974) indicate a good potential for ethephon use to enhance plant production from bedded sweetpotato roots.

\section{Literature Cited}

Deonier, M.T. and L.J. Kushman. 1960. The effect of presprouting and type of bed on the early production of sweet potato plants. Proc. Amer. Soc. Hort. Sci. 75:557-560.

Hall, M.R. 1986. Presprouting, root size, and cutting related to plant production by bedded sweet potato roots. HortScience 21(4):985-987.

Hall, M.R. 1987. Short duration presprouting enhances sweet potato plant production. HortScicnce 22(2):314.

Kushman, L.J., W.D. Drinkwater, and B. Graves. 1970. Plant production, p. 18-24. In: Thirty years of cooperative sweet potato research 19391969. Louisiana Agr. Expt. Sta., Louisiana State Univ., Baton Rouge. Southern Coop. Serv. Bul. 159.

Thompson, R.C. and J.H. Beattie. 1932. Proximal dominance in the sweet potato. Proc. Amer. Soc. Hort. Sci. 28:270-275.

Tompkins, D.R. and J.L, Bowers. 1970. Sweetpotato plant production as influenced by gibberellin and 2-chloroethylphosphonic acid. HortScience 5(2):84-85.

Tompkins, D.R. and R.D. Horton. 1973. Plant production by sweet potato roots as influenced by ethephon. HortScience 8(5):415-416.

Tompkins, D.R. and R.D. Horton. 1974. Sprouting of sweet potatoes from root pieces as influenced by gibberellic acid or ethephon. HortSciencc 9(4):392-393. 